\title{
Utasélmény a jegyértékesítésben és az utastájékoztatásban: közlekedési Service Design
}

Miért érzi magát az utas elveszve, amíg utazik, mit ért meg a körülötte zajló eseményekből? Versenyképességi korlát-e a közlekedés „bonyolultsága"? A HKIR (Helyközi Közösségi Közlekedési Információs Rendszer) az ország közösségi közlekedésének eddigi legkomplexebb informatikai projektje, amely bevezetése után évtizedekre határozza majd meg az utasélményt, és keretezi a helyközi közlekedés szereplőinek együttmüködését. A következőkben megtudhatjuk, hogy milyen alapelvek mentén építik fel a szerzők a rendszert, és hogy jutnak el ezekhez?

DOI 10.24228/KTSZ.2019.6.3

\section{Laskay Lóránt - Németh Ádám - dr. Tóth-Maros Dániel}

Közlekedéstudományi Intézet

e-mail: laskay.lorant@mav-start.hu, adam.nemeth@uxstrategia.net, toth-maros.daniel@mav-start.hu

\section{BEVEZETÉS}

A HKIR-projekt - teljes nevén „A személyszállítási közszolgáltatások hatékonyabb ellátását célzó integrált utastájékoztatási, jegyértékesítési és forgalomirányítási rendszerek fejlesztése" - Magyarország eddigi legnagyobb közösségi közlekedési projektje: egyszerre jogi, szervezési és müszaki vállalkozás. Arra hivatott, hogy egy egységes keretrendszert biztosítson a magyarországi közösségi közlekedés müködésére, lehetővé téve a jelenlegi szolgáltatók hatékonyságának növelését, a transzparenciát és a piacnyitást.

Mivel ez évekre, évtizedekre meghatározza a közösségi közlekedést, az utasok elvárásainak nem csak a funkcionalitás, de a használhatóság, élményszerüség szempontjából is meg kell felelnie.
Ebben segít a Service Design, ami azon tevékenységek összefoglaló neve, amelyek szervezik egy szolgáltatás szervezeti, infrastrukturális, kommunikációs és fizikai komponenseit a minőség és a szolgáltató és az igénybevevők közti interakció javítása érdekében.

A szerzők a HKIR-rendszer kialakítása során megpróbálják azokat a máshol már kipróbált módszereket hasznosítani - a projekt tervezési, fejlesztési, majd üzemeltetési szakaszában egyaránt -, amelyek a szolgáltatás, a szolgáltató és az igénybe vevők közti interakciót javítják.

\section{AZ UTAS INFORMÁCIÓIGÉNYE: ÉLMÉNYIGÉNY?}

\subsection{Az utas, a rendszer és az élmény}




\section{Közösségi közlekedés - szolgáltatásfejlesztés}

\subsubsection{A felhasználói élmény}

Egy közkeletű definíció szerint a felhasználói élmény azon érzések és gondolatok összessége, amelyeket egy ember átérez egy rendszerrel való találkozás során [1]. Ez természetéből fakadóan egyéni, egyszeri és helyzetfüggő, hiszen bármelyikünkkel elöfordult már, hogy az amúgy naponta használt rendszereinket (legyen az a bejárati ajtó zárja, egy fiók vagy egy szoftver) hangulati okokból egy-egy alkalommal képtelenek vagyunk használni, vagy rossz érzéseket keltenek bennünk. Nem csak a rendszeren múlik tehát: a zár ugyanaz, a kulcs ugyanaz, és nekünk ma valahogy mégse sikerül könnyen bezárni vagy kinyitni, pedig „amúgy szokott”.

Ugyanakkor azt is látjuk, hogy egy rendszer felhasználói élménye összességében, nagytotálban, a sok felhasználó miatt vagy épp a sok használat során korrelál, azaz mégiscsak a rendszeren múlik.

A közlekedési rendszerre ugyanígy értelmezhető a felhasználói élmény, mivel e tanulmányban nem az üzemeltető, hanem a laikus felhasználók vannak fókuszban, nevezzük ezt utasélménynek. Tehát az utasélmény nem más, mint az utas, mint felhasználó felhasználói élménye egy közlekedési rendszerrel szemben.

\subsubsection{A közösségi közlekedés mint dinami- kus rendszer}

A rendszer, amelyben az utasélmény keletkezik, a közösségi közlekedés; legfőbb jellemzöje, hogy soha, egyetlen napon sem jelenthető ki sem Magyarországon, sem a világ bármely más, hasonló méretü üzemmel rendelkező országában, hogy a tervezett menetrend bármely nap teljes egészében, változtatás nélkül teljesült volna - ez az ekkora méretű rendszerek sajátja. $A$ járművekben müszaki hibák léphetnek fel, az időjárás lehetetlenné teszi a közlekedést, balesetek történnek, útfelújítások kezdődnek stb.

Így az utasélmény tárgyalásakor is tisztázandó egy nagyon-nagyon fontos kérdés: a terv szerinti müködésen mint normálállapoton túllépve, hogyan értékelendő, ha ez a terv meg- hiúsul? Különösen távolsági közlekedésben ennek hatalmas hatásai lehetnek, mégse mindegy, hogy az utolsó szerelvényt nem érjük el, és így ragadunk egy idegen városban, vagy törlik a repülőjáratunkat stb.

\subsection{3. Élménycélok}

Ha a felhasználói élmény érzések és gondolatok összessége, milyen érzéseket, és milyen gondolatokat szeretnénk, hogy a rendszer kiváltson? Mik a céljaink a rendszer tervezésekor?

$\mathrm{Az}$ érzéseket tekintve legegyszerübb talán Ekman hat alapérzéséböl kiindulni [2], amelyek kombinációja a többi, bonyolultabb érzelem: a boldogság, a düh, a meglepetés, a szomorúság, a félelem, az undor. Legkevesebb, amit egy közlekedési rendszertől elvárhatunk, hogy ne keltsen érzéseket egyáltalán, ha kelt, akkor csak boldogságot keltsen - félelmet, dühöt, undort ne, és bár a rendkívüli helyzet automatikusan meglepődéssel jár, ezt is igyekezzünk minimalizálni - hiszen a legjobb haváriakezelés az, amiből az utas semmit nem vesz észre

\subsubsection{Ki az utas?}

A rendszeren túl a felhasználó előélete, eddigi tapasztalatai és a használati szituáció is erős befolyásoló tényező a felhasználói élmény szempontjából. Így fel kell tennünk a kérdést: kinek tervezünk? A legvédtelenebb egyértelmüen az az utas, aki elöször használja a rendszert, akár külföldiként, így nincsenek előzetes ismeretei. Mikortól feltételezzük, hogy valaki önálló utas? Egy csecsemő szinte biztos nem az, egy óvodás? Egy általános iskolás? Gondoljunk a fogyatékosággal élőkre is: egy nagyothallónak, színtévesztőnek nyilván használnia kell a közösségi közlekedést, és az Aspergerszindróma se lehet akadály, de hol jelöljük ki pl. az autizmusban szenvedők spektrumán azt a szintet, ahol még önállóan kezelhető rendszert kell tervezni? Az átlagtól eltérő utas átlagtól eltérő helyzetben igazi szakmai kihívás: mi történik, ha egy ritkán utazó, tájékozatlan, külföldi, esetleg fogyatékossággal rendelkező utas haváriahelyzetbe kerül? 


\subsection{Kapcsolat az utas tájékozottsága és az utasélmény között}

\subsubsection{Az utas hozott információinak szintje}

Kezdetnek érdemes abból a tapasztalásból kiindulnunk, hogy a közösségi közlekedés utasainak közlekedésföldrajzi ismeretei általában csekélyek, és generációról generációra sem mutatnak javulást. Gyermekeink egyre magasabb életkorban közlekednek elöször egyedül a városban, vesznek igénybe közösségi közlekedési eszközt (ha egyáltalán), ez sem a magabiztos önálló közlekedés képességének kifejlődése irányába hat. A közösségi közlekedés egyéni helyváltoztatási módokkal szembeni versenyhátrányának összetevői közül, ha nem is tolakodóan, de felsejlik az imént említett készségek-képességek pótlásának lehetősége: ha egy autóban nincs gyárilag navigáció, akkor is olcsón beépíthetö, ezután mi sem egyszerübb, mint hallgatni rá. Egy közösségi közlekedési eszközök sorát magában foglaló utazási láncban ugyanez a támogatás nem egyenletes színvonalú, vagy gyakran teljesen hiányzik. Hagyományos menetrendkönyvvel az utasok többsége nem vesződik (amúgy is egyre nehezebben hozzáférhető), az utazástervezéshez igénybe vehető megoldások pedig nem mindig támogatják, hogy az utas tér- és időérzékelése számára elegendő információ gyüljön össze (milyen útvonalon érem el az úticélt, mi indokolja éppen ezt a menetidőt). Amióta a „fapadosok" a repülővel történő utazás lehetőségét tömegek számára elérhetővé tették, az utazási lehetőségek térben ábrázolva egyenletes, a távolsággal hozzávetőlegesen arányos rendszerét összekuszálták: Budapestről gyorsabban elérhető London, mint (közösségi közlekedéssel) Aggtelek, könnyen lehet, hogy sok budapesti kisgyereket is ebben a sorrendben visznek el e két településre.

Az utasok többsége valószínűleg nem komplex, müködő rendszerként tekint a közlekedésre, fókuszában a saját utazási igénye és az annak kielégítésére összeállított utazási lánc áll, ennek az utazási láncnak a környezetéböl más elemeket homályosan vagy egyáltalán nem észlel. A rendszeres utazóknál felismerhető egy tapasztalati úton történő tanulás, amely során az utazását körülvevő környezet ismétlődő elemeiből egyre többre emlékezik és ezzel néhány összefüggést is felismer. E felismeréseknek például olyan módon ad hangot, hogy aktuális beszélgetőtársával (utastársával vagy valakivel a telefonvonal túlvégén) megosztja a tudását: „A szembejövő vonat miatt állunk.” „Itt mindig dugó szokott lenni.” „Ennyi késést nem szokott behozni.” A közlekedési szolgáltatók szerencsétlenségére a tervtől eltérő események, problémák jobban bevésődnek, mint az egyébként gyakori, de nem túl érdekes menetrend szerinti utazások. Az utasok összességének „kollektív tudatában” a jegyváltási kötelezettségre vonatkozó ismeret is jelen van, Magyarországon kinek-kinek a saját kedvezményére vonatkozó nagyfokú tudatossággal. $\mathrm{Ez}$ az ismeret rendszeres utasnál több, alkalmi utasnál kevesebb, fiatalabbnál támogatja egy készség az önkiszolgáló rendszerek - például automaták - kezelésére, az idősebbeknél viszont gyakran nem.

Mit tud a tipikus utas az utazás megtervezését megelőzően? Elsősorban az úticélt, rögtön ezt követően a célba érés hozzávetőlegesen ideális időpontját. Ha valaki ezeket nem tudja, atipikus utasnak kell tekintenünk. Az utasnak lehetnek további preferenciái is, de ezek hiányában is a két alapinformáció egészül ki az utazási lehetőség keresése közben azzal, hogy milyen utazási idő, milyen utazási költség és milyen utazás közbeni szolgáltatási színvonal (ideértve azt is, hogy milyen közlekedési eszköz - autóbusz, hajó, repülő) érhető el a kívánt úticélra és érkezési időre. Leegyszerüsítve ez az utazási ajánlat, az utas hozott tudásának és a szolgáltató szolgáltatási katalógusának a metszetében. Az utazási ajánlat annak szerződéssé szilárdulásával egyidejűleg kiegészül az utas már tárgyalt hozott ismereteivel és mindazzal, amiről a szolgáltató tájékoztatni próbálja őt.

\subsubsection{Releváns és irreleváns utazási infor- mációk}

Ha az utazást jogászi szemlélettel szerződésnek vagy szerződések rendszerének tekintjük, akkor az utazás sikerességét (a szerződésbe nehezen foglalható szubjektív élvezeti értéken kívül) a felek szerződésszerű teljesí- 


\section{Közösségi közlekedés - szolgáltatásfejlesztés}

tésén mérhetjük le [3]. Az utas szempontjából akkor sikeres az utazás, ha a szolgáltató az ajánlata szerint vagy legalábbis az utas számára még megfelelő időben és szolgáltatási színvonalon teljesítette a feladatát. E kettőt azért érdemes szétválasztani, mert nem minden szolgáltató oldali hibás teljesítés okoz feltétlenül bosszúságot vagy kárt az utasnak. Egy csekély mértékü késés bizonyos típusú utazásoknál elfogadott, a példa szerint az iskolásokat szállító vonatok késése pedig sok, első óráról elkéső tanulónak tud örömet okozni. A szolgáltató szempontjából akkor sikeres az utazás, ha az utas a rá vonatkozó szerződési feltételeket teljesítette, elsődlegesen az utazásért felszámított díjat megfizette, emellett a magatartási szabályokat megtartotta, és a szerződés teljesítéséhez szükséges egyéb együttműködési kötelezettsége (például megfelelö okmányok bemutatása, időben történő megjelenés meghatározott helyen) is megfelelő volt.

Az utazás sikerességének fenti, szerződéstani megközelítéséből az következne, hogy minden, a szerződés teljesítését elősegítő információ potenciálisan releváns. Ha az utas többet tud az utazásról, könnyebb szerződésszerű magatartást tanúsítania. A szolgáltatóra ugyanez igaz. A sikeres utazás receptjében mégsem szerepel a végtelen mennyiségű információ, ennek három oka van:

- Az utas hozott ismeretekkel rendelkezik, - bármily csekély mértékben is számíthatunk rá a korábban írt okokból.

- Az utas „spontán jogkövetésére” nagy valószínűséggel számítani lehet. Ebbe a magatartásba sok minden belefér, kezdve attól, hogy nem tanúsít olyan magatartást, amely a józan esze szerint veszélyes vagy törvénytelen lehet, odáig, hogy a közlekedési szolgáltató adhoc kéréseit, utasításait is figyelembe veszi (nem kell minden eshetőségre előre felkészíteni).

- Az utazáshoz kapcsolódó információ mennyisége egy kritikus ponton túl bizonytalanságot, félelmet szül az utasban, ennél is gyakrabban barátságtalan, bürokratizált eljárásokat vetít számára előre. Ennek a „kevesebb néha több” szemléletnek megfelelően kell rendszereznünk a tájékoztatási feladatokat.

\subsubsection{A „tájékozottság” utasjogi dimenziója}

Az utastájékoztatás elnevezése egyoldalúságot sugall (az utast tájékoztatja a szolgáltató), valójában azonban egyértelmüen kétirányú. Számos utastájékoztatási mozzanat az utas kezdeményezésére történik (például kérdez valamit), és számos tájékoztatás váltja ki az utas reakcióját. Az utastájékoztatás jelentőségét mi sem mutatja jobban, mint hogy az ágazati utasjogi rendeleteken keresztül az Európai Unió fogyasztóvédelmi fókuszú jogalkotása is foglalkozik vele.

Ha például a vasútra vonatkozó szabályozást vizsgáljuk, a vasúti utasjogi rendelet az utastájékoztatást a szerződés megkötését megelőző, utazás közbeni, valamint a jogokról történő tájékoztatásként azonosítja. Világos, hogy ez a csoportosítás nem tartalmazza valamennyi tevékenységet, a szabályozás szempontjából legfontosabbakat azonban igen. Az összes utastájékoztatási tevékenység feltérképezése ennél összetettebb képet ad.

$\mathrm{Az}$ első csoportba - az utasjogi rendelet felosztásával összhangban - azok a tájékoztatási elemek kerülnek, amelyek a szerződés megkötését segítik. Ide tartoznak azok az információk, amelyek a vasúti társaság szerződéses ajánlatának forrásai: a menetrend, a díjak, a szolgáltatások, az összes előzetesen megismerhető utazási feltétel, díjszabás is.

A második csoportba tartozó, szerződés teljesítését segítő utastájékoztatási tevékenység célja összetett és iránya is kettős:

- részben a szállító szerződésszerű teljesítését szolgálja (ha nem tájékoztatna, szerződést - sőt, jogszabályt - sértene),

- részben az utas szerződésszerű teljesítését segíti elő (hol a vonata, mikor kell leszállnia, hogyan viselkedjen).

Bár az utasjogi rendelet itt a fedélzetre helyezi a hangsúlyt, az utazás tág értelemben vett megkezdésétől a célállomásra történő megér- 
kezésig több csatornán nyújtott összetett tájékoztatásról van szó.

A tájékoztatási feladatok harmadik csoportja zömmel a szállító és az utas forgalmi akadály miatti kényszerü egymásrautaltságát támogatja, tehát a szerződésszerű teljesítés (újbóli) folytatását vagy a szerződésszegés következményeinek érvényesítését segíti elö.

\subsubsection{A megfelelö információ megfelelö formában: élmény}

Az utazáshoz kapcsolódó pozitív érzések kialakulásához szükséges összetevőkre a közlekedési szolgáltatónak változó mértékben van ráhatása. Az utazással töltött idő hosszára gyakorolt hatása összetett, de világos. Az utazási idő élvezetes eltöltésére vonatkozó javaslatokat vagy tesz, vagy nem, de elöbbi esetben is az utas vagy él e lehetőségekkel, vagy nem. Az utastársak megválasztásában a szolgáltatónak nincs szándékolt szerepe. A táj szépsége, az időjárás, az utas pillanatnyi hangulata adottság.

A szolgáltató birtokában van azonban annak képessége, hogy az utast információkkal lássa el az utazás zavartalan lebonyolítása érdekében. E képesség az utazással járó bizonytalanság, feszültség mérséklésére alkalmas, sőt, lehetőséget ad az utasnak, hogy az utazásával kapcsolatban a „jól megszervezettség” érzése árassza el. Ez azt jelenti, hogy a tudás hiánya, az elveszettség, a kényelmetlen feszültség helyett az utast tudáshoz, magabiztossághoz és nyugalomhoz juttathatja a szolgáltató.

\section{SZAKMAI FORRÁSOK ÉS ELÖZMÉNYEK}

Egy rövid történeti áttekintéssel kezdjük a Service Designról, majd bemutatjuk azokat a projekteket, amelyek közvetlenül megelőzik a mostani projekt tervezését.

\subsection{A Service Design és kialakulása}

Bár a Service Design kifejezést jellemzően a kölni International School of Design-hoz szokás kötni, azon belül is Prof. Dr. Michael
Erlhoff 1991-es kijelentéséhez [4], valójában előzményei a történelem meglepően távoli pontjaiban is megláthatók. Az egyszerüség kedvéért most mégis a 20. század második felétől indítjuk a történetet.

\subsubsection{A skandináv modell [5]}

A rendszerkialakításban a leendő felhasználók bevonását sokan „skandináv modellnek” hívják, hisz az ottani szakszervezetek ezt már a 60-as 70-es években kikényszerítették. Mint azt később látni fogjuk, egy rendszer hibáit okozhatja az, hogy a rendszer megrendelöje a napi folyamatban aktuálisan résztvevő végfelhasználókat pusztán „betanítja” az új rendszerekre, a fejlesztés jórészt tőlük függetlenül zajlik. Ezt a HKIR projektben igyekszünk elkerülni, folyamatos és minél közvetlenebb kapcsolatot próbálunk fenntartani a rendszer szereplöivel. Ebben segítségünkre van a Közlekedéstudományi Intézet (KTI) fóépületének elhelyezkedése, közvetlenül a kelenföldi autóbusz-pályaudvar és vasútállomás mellett.

\subsubsection{A User Experience Design (felhaszná- lói élmény-fókuszú rendszertervezés)}

Nem lehet a Service Designról értekezni manapság az informatikai rendszerek tervezését meghatározó User Experience Design nélkül, föképp, hogy a HKIR rendszer elsősorban egy informatikai rendszer. A User Experience Architect (felhasználói élmény-tervező) munkakör titulust először Donald Arthur Norman alkalmazta, amikor az Apple Computers csapatához csatlakozott. Az első átfogó tanulmány a témakörben az 1983-as The Psychology of Human-Computer Interaction (Az emberszámítógép interakció pszichológiája) [6].

\subsubsection{A Service Blueprint (szolgáltatásmeg- valósítási térkép)}

Felismerve, hogy a szolgáltatások folyamatai több rétegen mennek keresztül, amelynek nagy része a végfelhasználó (esetünkben az utas) számára láthatatlan, a hiányosságok pedig gyakran ezekben az alsó, a vevővel már közvetlenül nem interaktáló rétegekben keletkeznek. A ma használatos Service Blueprint 


\section{1. ábra: Az IDEO és a d.school klasszikus ábrája a Design Thinking folyamatáról}

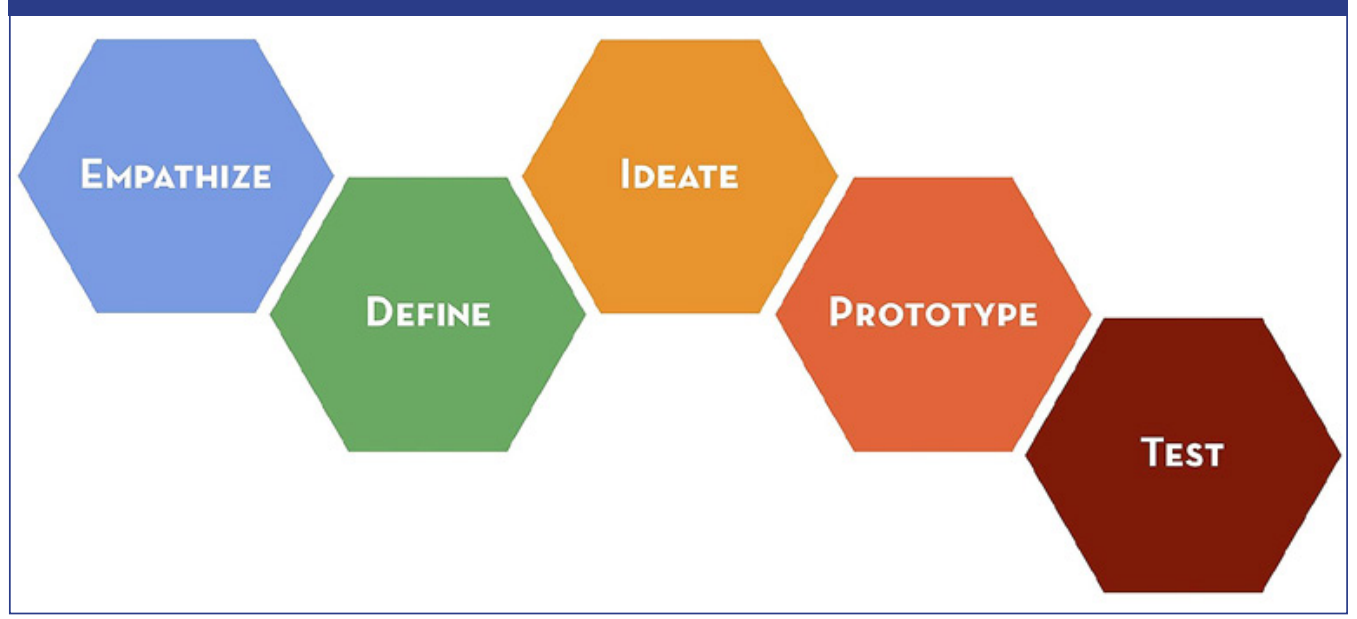

diagramok elődjét Lynn Shostack publikálta 1984-ben a Harvard Business Review hasábjain [7]. A HKIR rendszer is azon az elgondoláson alapszik, hogy az utas élményét nem pusztán az általa észlelhető szolgáltatások - mint pl. a jegyvásárlási és az utastájékoztatási felületek - befolyásolják, hanem az alatta dolgozó emberek ezreinek munkája is meghatározó szerepet fog számára betölteni (gondoljunk csak az üzemirányítást végző diszpécserek kommunikációjára, vagy épp a megállót tervező térképészek precizitására).

\subsubsection{User Centered System Design és Human-Centred Design (felhasználóközpontú tervezés és emberköz- pontú tervezés)}

Manapság már (a később tárgyalandó ISO szabvánnyal összhangban) egybeolvadt a két fogalom, az előbbi mégis [8] kutatáshoz köthető (és a szabvány is elsősorban ebből táplálkozik), míg a második Mike Cooley építész technológiapolitikai írásaival jött létre. Egy „utasközpontú” rendszert kizárólag ezen elveknek megfelelő módszerekkel lehet megtervezni.

\subsubsection{Design Thinking (designgondolkodás)}

Peter Rowe 1987-es könyve [9] volt az, amelyik a dizájnt mint gondolkodásmódot vezette be, ezzel egyértelmüen elemelve a vizuális grafika világától. Maga Rowe urbanisztikai szakemberként várostervezési szempontból mutatta be a tervezői gondolkodás fontosságát. Nem példanélküli az építészeti gondolkodás térnyerése más diszciplínákban: hasonló történt az informatikában Christopher Alexander mintanyelv-elméletének [10] kilencvenes évekbeli felhasználásakor. A mintanyelvekre itt ugyan narratív okokból nem térünk ki, de módszerünk alapelemei közé tartozik.

\subsubsection{Az IDEO cég megalakulása (1. ábra)}

Szintén nem lehet teljes egy Service Design történelmi körkép az IDEO megemlítése nélkül: a jelen módszertanok kidolgozásának jórésze az ő nevükhöz füződik, sokan a Design Thinking szót, a dizájn mint diszciplína általánosítását is hozzájuk füzik, főleg ügyvezetőjük 2009-es Change by Design [11] könyve nyomán. Jellemző rájuk a multidiszciplináris megközelítés, amit később a majdan részletezésre kerülő ISO szabvány is átvett: a HKIR projektben is egyszerre igyekszünk figyelembe venni pl. az informatikai, társadalomtudományi, jogi és közgazdaságtani aspektusokat.

\subsubsection{Perszónák és felhasználó-életciklusok}

Amit a perszónamodellezésről mindig el kell mondani: nem lehet perszónát tervezni együltő helyünkben, az pusztán egy megjelenítési for- 
2. ábra: A MÁV-Start szolgáltatásainak ergonómiai problémái az utas életciklusának függvényében [14] - Németh Ádám munkája a MÁV-START számára (részlet)

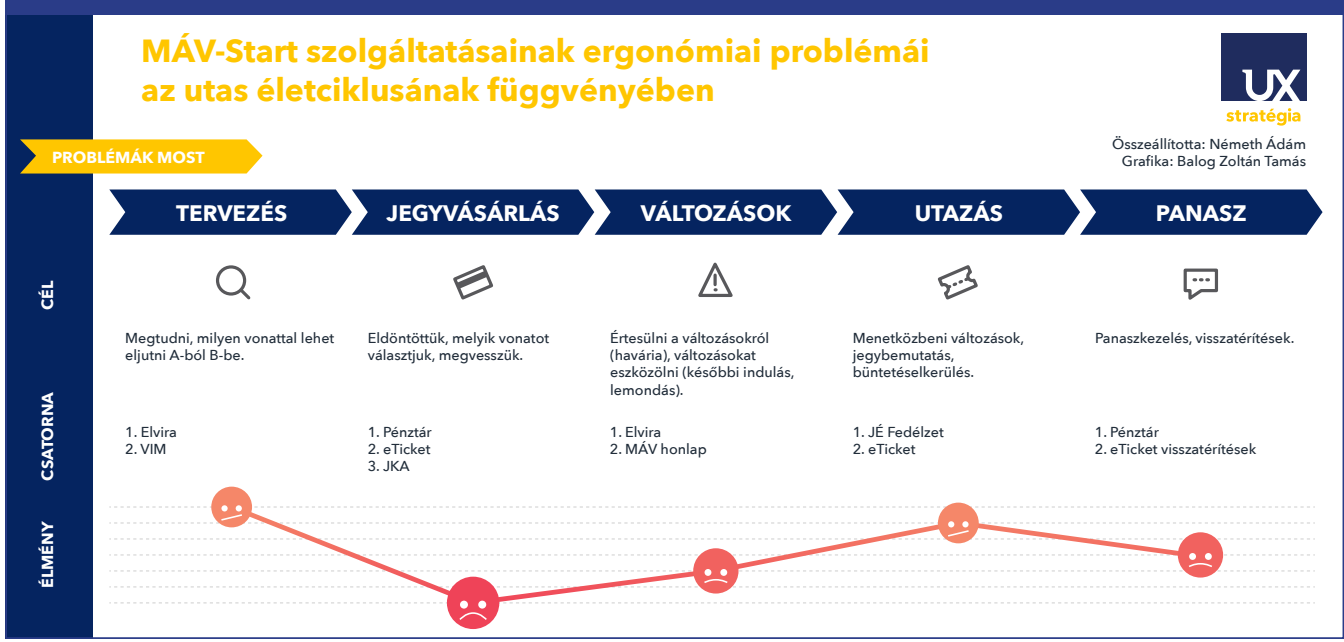

mája, összefoglalója társadalomtudományi kutatásoknak (rendszerint félstrukturált mélyinterjús, kontextuális kutatások és kvantitatív mérések összességének). Mindazonáltal a perszóna egy valamilyen szempontból jellemző felhasználói viselkedés archetípusa, amelynek tulajdonságai a kognitív pszichológiai modellekben gyökereznek. Ilyen perszóna a Földesi Fanni kutatásában később bemutatott valahova először utazó, átszálló egyetemista vagy épp egy kerekesszékes felhasználó. Gyakran érdemes a felhasználó viselkedését időben elemezni, olyan helyzetekre szakaszolva, ahol céljai, szükségletei a helyzet függvényében változnak, hívjuk ezt felhasználói (utas) életciklusnak, user journey-nek, élménytérképnek. Ezt bizonyítottan először az előbb említett IDEO ügynökség végezte el 1999-ben egy vasúti projekt [12] részeként.

\subsection{A RailEurope kutatása - Adaptive Path [13]}

Módszertanilag a legmeghatározóbb nemzetközi elözményprojektet az Adaptive Path ügynökség végezte a Rail Europe Inc nevü, vasúti jegyárusításra szakosodott egyesült államokbeli szervezetnek. Az évtized fordulóján zajló kutatás 2500 kitöltővel és több terepinterjúval rajzolta fel a vonattal utazás élménytérképét
Természetesen ez a kutatás egy másik korban (gyakorlatilag az okostelefonok elterjedésének hajnalán) egy másik közönségről (Európába utazni vágyó USA állampolgárok) szól, és a nemzetközi közlekedés szükségszerüen csak felületesen érinti a belföldi közlekedés jellegzetességeit, finomságait, gondoljunk csak a vasúti menetjegyek kedvezményrendszerére. Így aztán a kutatást, módszertani előnyei figyelembevételével, érdemes megismételni a jelen helyi viszonyokra is.

\subsection{A MÁV-START JÉ (jegyértékesítési) rendszerének újratervezése (2. ábra)}

A szerzők mindegyike így vagy úgy, de részt vett a MÁV JÉ rendszer fejlesztésében. Amikor 2015-ben a jegykiadó automaták tervezését [14], majd 2017-ben a pénztári és fedélzeti rendszerek felülvizsgálatát [15] végeztük, a RailEurope kutatáshoz hasonló módszertan szerint haladtunk.

Az említett felülvizsgálatra azért került sor, mert a felhasználók negatívan fogadták a JÉ rendszer bevezetését, ezen próbáltunk User Experience módszerekkel segíteni.

\section{Nem lehet eléggé hangsúlyozni a terepkuta- tás fontosságát: ha nincs}

- a többezer kilométer vasúti utazás,

- a jegyvizsgálók követése több vonaton, 
3. ábra: Hogyan jutok el oda? - Storyboard / képregény SAP Scenes felhasználásával Földesi Fanni diplomamunkájának részlete

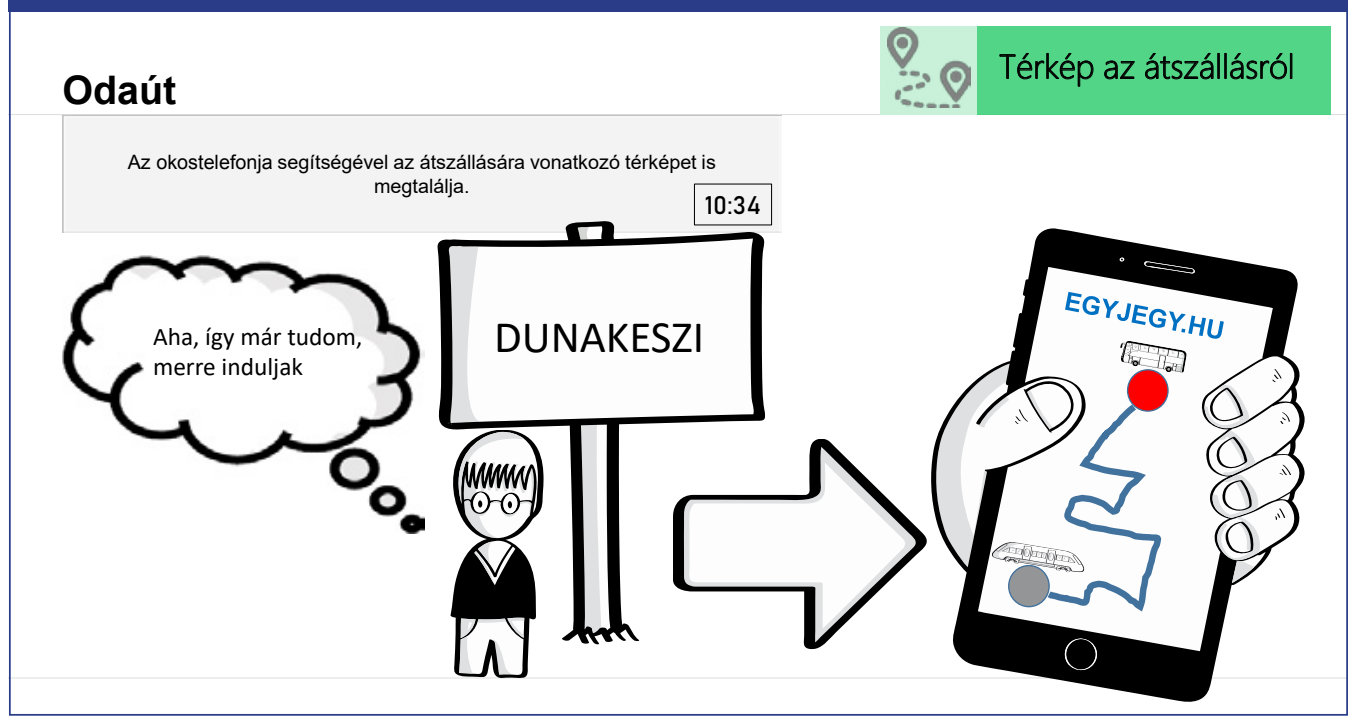

- teljes müszakok eltöltése pénztárablakokban,

- az utasok folyamatos kérdezése átgondolt módszertan szerint,

akkor közel se rendelkeznénk ennyire mély ismeretekkel arról, „mit is akar az utas”, melyek az egyes szereplők céljai, szükségletei, de legföképp problémái a mai megoldásokkal. Ezt nem lehet egy irodából megoldani, ehhez kiterjedt, életben tartott kapcsolatrendszert kell felépíteni a résztvevőkkel, és elsőkézből szerezni tapasztalatot. A közösségi közlekedés problémáinak legfőbb forrása pont az, ha kényelmi okokból az irodából próbálunk eldönteni kérdéseket.

\subsection{Földesi Fanni alapkutatása (3., 4. ábra)}

Szerencsés véletlen sodorta hozzánk Földesi Fannit, aki a Budapesti Műszaki és Gazdaságtudományi Egyetem Pszichológia és Ergonómia tanszékén épp akkor kezdte meg tervezni a diplomamunkáját [17] a vasúti automaták működéséből, amikor a HKIR projekt service design tervezése indult, akinek kutatási területe az intermodalitás lett. Alaptémája az a közösségi közlekedésben legtöbbször elhanyagolt momentum, amikor az utas először próbálja meg az átszállásokkal tarkított útját végrehajtani, s teszi mindezt úgy, hogy nem minden alakul a terv szerint. A feladata az volt, hogy találja meg mindazokat az eszközöket, amelyek ahhoz szükségesek hogy egy digitálisan tájékozódó erre önállóan képes legyen.

\section{A KIALAKÍTOTT MÓDSZERTAN}

A specifikációhoz módszertani segítségül elsősorban Donald Norman elveinek ISO szabványosított elveit vettük alapul, amelyet az ISO az ergonómiával foglalkozó 9241 szabványcsoport részeként, a 9241-210 számon [18] kodifikált.

A workshopokat az Adaptive Path munkatársai által kiadott Orchestrating Experiences [19] könyve alapján építettük fel.

\subsection{Az ISO 9241-210 alapelvei és annak értelmezése}

Az ISO 9241-210 hat alapelve a következő:

1. A specifikáció, tervezés és fejlesztés a végfelhasználók, az ő feladataik és az ő környezetük explicit és objektív megértésén alapul.

2. A végfelhasználók a specifikáció, a tervezés és a fejlesztés folyamatába végig be vannak vonva. 
Közösségi közlekedés szolgáltatásfejlesztés

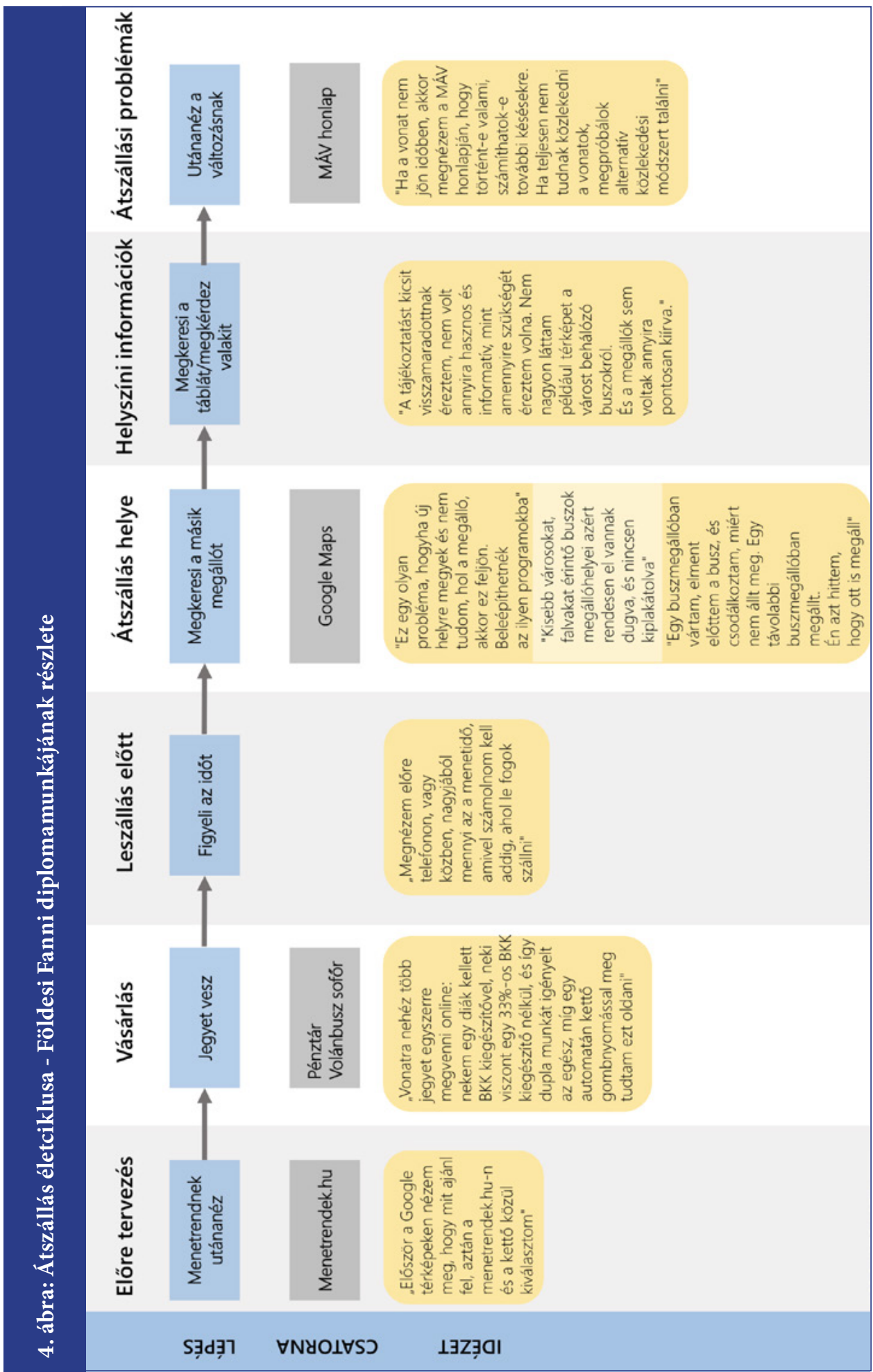


3. A specifikációk tervek, megvalósítások hajtóereje, minden változtatás alapja elsősorban a felhasználó szemszögéből történő kiértékelés.

4. A folyamat minden esetben többkörös.

5. A specifikációk, tervek kiterjednek a felhasználó teljes élményére.

6. A tervezői csapat különböző hátterü és nézőpontú emberből áll.

A mi értelmezésünkben ez a következőket jelenti:

\subsubsection{Kötelezö környezetvizsgálat a teljes tervezői csapat bevonásával}

A környezetvizsgálat elsődleges célja a tacit-explicit - a meg nem nevezett vagy a megfogalmazott -tudás felszedése és empátia keltése a felhasználó fele. Ezt megpróbáljuk mindig perszónákba és customer journey-kbe önteni, de valójában definíció szerint a megfoghatatlant próbálnánk vele megfogni.

A potenciális felhasználó az olyan ember, aki jelenleg olyan tevékenységet végez, amit a jövendő rendszer megold vagy kivált. Még ha a rendszer nem is létezik most, a helyzet, amibe beleszületik, akkor is létezik (hiszen ha az sincs, akkor nem lesznek felhasználói se), és azokat az embereket kell megtalálni, akik ebben a helyzetben vannak. A kulcsfelhasználók bevonása nem rossz ötlet, de egyfelöl nem ad tacit tudást a környezetről, másfelöl egy kulcsfelhasználó szavatossági ideje két év: ennyi idő az eredeti felhasználói feladattól távol, és az illető többé nem kulcsfelhasználó, hanem egy a projekt belső emberei közül. A tapasztalata így is hasznos, de elengedhetetlen, hogy a csapat friss képet kapjon. Az ilyen "valaha felhasználó voltam" szakértők eleinte idegenkednek attól, hogy a projekt többi résztvevője terepre menjen, holott sokkal több szavuk lesz a folyamat végén.

Az objektív megértés alapja a "miértek" megértése. Ezért a környezetvizsgálat majdnem mindig kvalitatív és személyes. A környezetvizsgálatnak van egy kötelező módszertana: ez a félig strukturált mélyinterjú és megfigyelés, aminek megvan a kérdésrendszere. Hogy milyen szakmai követelményei vannak a környezetvizsgálatnak, az viszont túlmegy ezen írás keretein.

\subsubsection{Tényleges felhasználói adatbázis fenn- tartása és rendszeres használata}

A felhasználókat az ISO szabvány alapján folyamatosan be kell vonni: ennek a legegyszerűbb módja egy erre szolgáló adatbázis (hírlevél, CRM (ügyfélkapcsolat-menedzsment) vagy excel-tábla) kezelése. Miről kérdezzük meg a felhasználókat? A válasz az, hogy mindenről: minden tervezési döntést felhasználói véleményeztetésre kell küldeni, méghozzá közérthető formában. Ennek a service design világban nagy hagyománya van, elsősorban a képregények (storyboardok), és az interaktív prototípusok azok, amik ezt lehetővé teszik. A gyakorlatban a minimum az, hogy a funkcionális specifikációt mindenki láthatja, mielőtt elindul a fejlesztés, és folyamatos, egyesével tartott tesztek zajlanak a prototípusokon és a készülő terméken egyaránt.

\subsubsection{Folyamatos prototipizálás és használ- hatósági tesztelések}

Az interaktív prototípus a funkcionális specifikáció legérthetőbb formája. Ez az, amit az is véleményezni tud, aki épphogy csak megtanult írni-olvasni, és az is, akinek négy diplomája van, de csak 3 perce van az egészre. Az interaktív prototípus elsődleges célja, hogy szabványos használhatósági teszteken ellenőrizzék a működését tényleges felhasználókkal: ehhez egy csomó szabályt be kell tartani ismét, amibe most részletesen nem fogunk belemenni. Amit mindenesetre érdemes megjegyezni: ahhoz, hogy egy ilyen prototípus tesztelhető legyen, konkrét példaadatokkal, egy összefüggő feladaton kell keresztülmennie, több használati módot, sorrendet támogatva. A tesztelővel ellentétben ugyanis a felhasználó nem konkrét lépéseken megy keresztül, hanem a feladat céljának ismertetése után önállóan próbál navigálni a rendszerben, és ritka az, hogy olyan sorrendben nyomja meg a gombokat, ahogy az egyszeri tervező azt elképzelte. 


\subsubsection{Minden folyamat legkésőbb felénél kezdödnek a használhatósági tesztek}

A hagyományos elfogadási tesztelés (User Acceptance Test UAT) legnagyobb hátránya, hogy akkor már rendszerint a projekt költségvetésének döntő többségét elköltötték. Ugyanez a helyzet a használhatósági tesztekkel is. Ezért van az, hogy sem a tervezési, sem a fejlesztési időszakban nem szabad megvárni a rendszer befejezését. A használhatósági teszteknek a változtatási kérések elsődleges forrásának kell lenniük: ez igaz mind a funkcionális specifikációra, mind a tényleges, kifejlesztett rendszerre. A használhatósági teszteknek a változtatási kérések elsődleges forrásának kell lenniük. Mivel a funkcionális specifikációnak vagy rendszertervnek rendszerint nem része a kötelező interaktív prototípus, így teszteket se lehet rajt végezni, csak a tényleges rendszeren. Ha viszont a felhasználók azelött látják a rendszert, hogy azt elkezdenék lefejleszteni, a hibák azelőtt felszínre kerülnek, mielőtt a projekt költségvetésének lényegi részét elköltötték volna.

\subsubsection{A teljes szolgáltatást kell közérthetö- en modellezni, nem csak az informatikai rendszert}

Nagyon gyakran szembesülünk azzal, hogy a szolgáltatás koncepciója rossz, és innen hiába csinálunk egy jó felületet rá, az rúzs a disznón:

\subsubsection{A prototípusokat mindenki vélemé- nyezhesse, akinek köze lesz a rendszerhez, föleg ha kívïl esik a projekt csapatán}

Gyakran látunk olyat, hogy a belső szakemberek összeraknak egy rendszert, nem is gondolva arra, hogy milyen érzés lesz ezt egy nem szakértőnek használnia. A másik gyakori hiba, hogy a projekt csapat kialakít egy belső nyelvet, saját kifejezésekkel, amiket aztán megpróbál „megtanítani” a felhasználóknak.

\subsection{Az élményrendezés módszertana (5-8. ábrák)}

\subsubsection{Helyzetértékelés, problémafelvetés}

Jelenleg Magyarországon több személyszállí- tási közszolgáltatást végző társaság biztosítja a közösségi közlekedést az Innovációs és Technológiai Minisztérium és a helyi önkormányzatok megrendelése alapján. A közszolgáltatás megrendelőjénél vagy annak megbízottjánál ugyanakkor nincs olyan központi szervezet, amely eszközparkját és humán állományát tekintve alkalmas a szolgáltatási színvonal folyamatos vizsgálatára, az elvárt szolgáltatás főbb paramétereinek aktív és rögzített figyelemmel kísérésére. Az előírt időszakos adatszolgáltatások és a megrendelői beszámoltatások, mérések, ellenőrzések csak az elvárható adatok egy részét tárják fel, nem adnak reális és teljes körü képet a szolgáltatásokról.

Az egyes szolgáltatók, például a MÁV-Start Zrt. és a regionális közlekedési központok, valamint az önkormányzatok által finanszírozott helyi közösségi közlekedési közszolgáltatók rendszerei között nincs átjárhatóság, így az utazási jogosultságot biztosító menetjegyek esetében sem. Amennyiben valaki közlekedési eszközt vált - pl. vasútról autóbuszra, de akár a regionális autóbusz társaságok között is - jelenleg több, külön szolgáltatási és informatikai rendszert használ. Magyarországon nem müködnek olyan jegyautomaták, amelyek több szolgáltató jegyeit értékesítik. Előre tervezetten az utas egy rendszeren keresztül nem tud utazási láncolatot tervezni és jegyet váltani, ezáltal mérhető idővesztesége keletkezik.

Hiányzik a korszerü elektronikus csatornákon (internet, mobil alkalmazás) történő helyközi viszonylatú jegyértékesítés, valamint a korszerű elektronikus kártyák (pl. elektronikus személyazonosító igazolvány, eSZIG) használatával történő kedvezmény igénybevétele és elszámolásának lehetősége.

A menetrendek tervezésekor az előzőek miatt nehéz feladat a rendelkezésre álló adatokból pontosan felmérni a valós utazási igényeket. A helyi és helyközi közlekedést is igénybe venni kívánó utazástervezések és a végül megvalósult ilyen utazások volumene például teljesen láthatatlan marad. A szolgáltatóknak ezért nem róható fel, hogy erős szakmapolitikai iránymutatás nélkül a hosszú utazási láncokat támogató kooperációban nem különösebben 
5. ábra: Oppurtunity mapping workshop (lehetőségfeltáró workshop) az Orchestrating Experiences c. könyv alapján, 2018 ősz

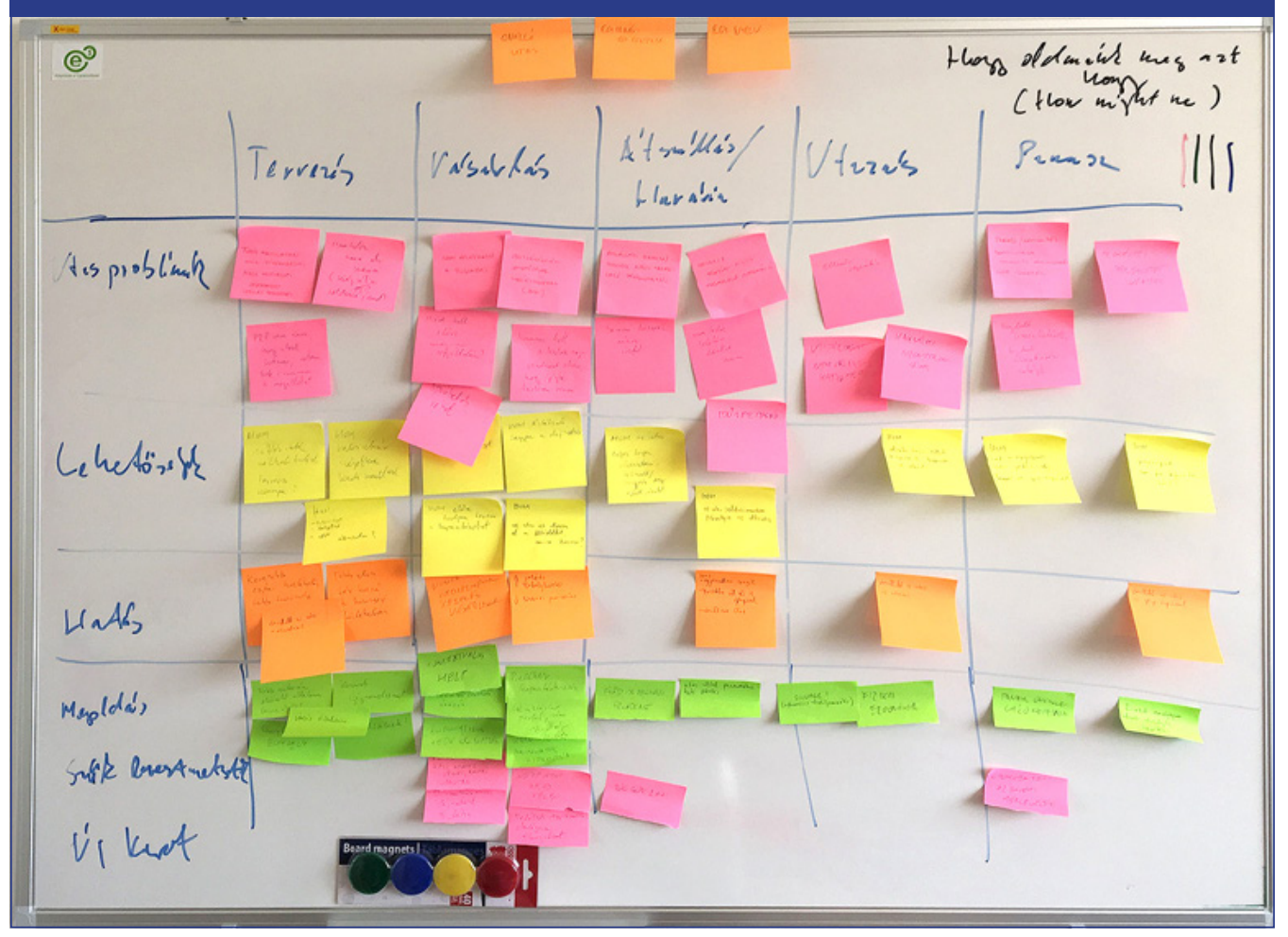

érdekeltek. Az értékesítési adatok hiányosságai egyaránt eredményezhetnek ezen kívül kihasználatlan vagy kapacitáshiánnyal küzdő járatokat. A jelenlegi menetrendtervezési gyakorlat mellett elöfordul, hogy a csatlakozások nincsenek összehangolva, az autóbusz nem várja be a vonatot, viszont a különböző közlekedési módokat üzemeltető társaságok versengve, a párhuzamos vonalakon egymástól veszik el az utasokat (sokszor az egyik ágazatot sem választó, jelenleg egyéni közlekedéssel utazók igényeit teljesen figyelmen kívül hagyva).

Mindez megfelelő fejlesztés nélkül a szolgáltatással elégedetlen utasokhoz, versenyképtelen és fejlesztési tartalékkal nem rendelkező, fenntarthatatlan mértékü állami szubvencióra szoruló közösségi közlekedési rendszerhez vezet. A szolgáltatók saját forrásból az elmúlt 30-40 évben jelentős fejlesztést nem tudtak megvaló- sítani, napi szinten gondot okoz az üzemeltetés fenntartása is a karbantartás elmaradása miatt leromlott állapotú infrastruktúra elemeken, illetve eszközökön. A hosszú távú utazások esetében ez a közösségi közlekedés további térvesztéséhez és a jelentős környezetterhelést eredményező személygépkocsi-használat növekedéshez vezet. Az állami fenntartású vállalatok, fejlesztések hiányában jelentős versenyhátránnyal indulnak a további esetleges piacliberalizáció során.

Az előző feltételezéseket szem előtt tartva, a különböző szereplők bevonásával (közösségi közlekedés területén döntéshozói szereppel rendelkezők; a közösségi közlekedést napi szinten használók; közösségi közlekedési módokat nem használók) workshopokat szerveztünk, ahol a Service Design módszertanát alkalmaztunk, ami a közösségi közlekedés helyzetének, problémáinak mélyebb és rész- 


\section{Közösségi közlekedés - szolgáltatásfejlesztés}

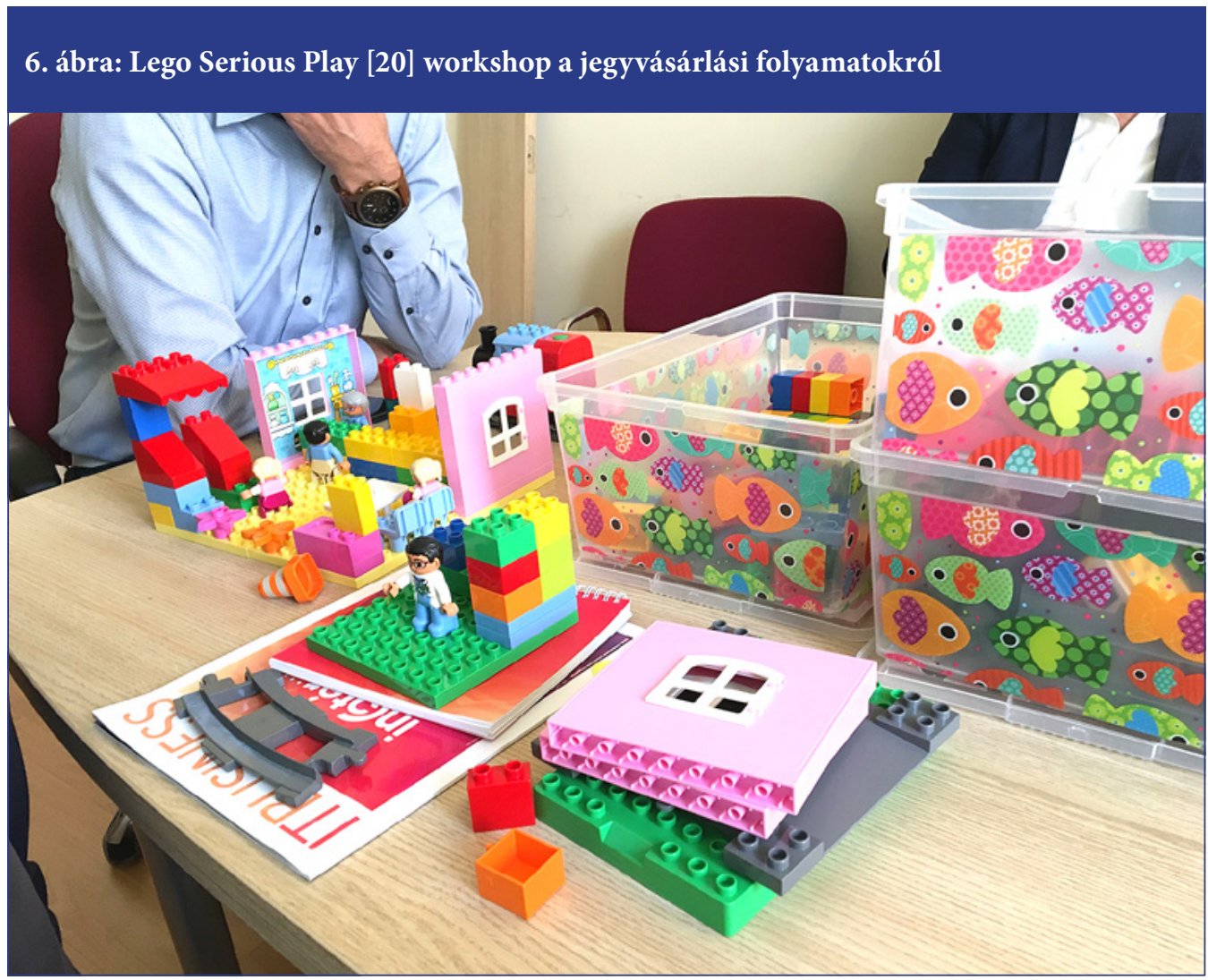

letesebb megismerésére, feltérképezésre és alternatív megoldások, válaszok kialakítására fókuszált. A workshopok és az alkalmazott módszertan célja, hogy kialakítsuk a jövőbeli közösségi közlekedési informatikai rendszer fejlesztésénél figyelembe veendő társadalmi és alapelv rendszert.

A módszertan egyik hatékony eszköze, a 'How might we' problémafelvetési formátum, aminek segítségével a résztvevők által azonosított problémákra a „Hogyan oldanánk meg”-kérdés felvetésével megoldásokat, hatásokat és szűk keresztmetszeteket határozunk meg, majd ezeket a résztvevők visszajelzéseinek előfordulási gyakorisága szerint priorizáljuk. A workshopokon az előzetesen meghatározott utas életciklus folyamatelemeire vetítve készítettük el az elemzést. A továbbiakban az egyes ciklusokhoz kapcsolódóan kiragadtunk egy-egy példát, hogy bemutassuk a módszertan lényegét.

\subsubsection{Utazástervezés}

Az egyik gyakran felvetett probléma a jelenlegi közösségi közlekedésben az utazástervezéssel kapcsolatban, hogy egy A-ból B-pontba vagy C-pontba történő utazástervezés esetén több felületen kell tájékozódni, nincs egységes tervezési felület a teljes utazási láncra vonatkozóan, ahol pontos információkat kaphatunk az utazás feltételeivel (átszállási lehetőségek, jegyárak, kényelmi szolgáltatások, kiegészítő információk) kapcsolatban. A jelenleg az utasok rendelkezésére álló rendszerek egy módváltást igénylő utazás esetén csak részben, a szolgáltatók által üzemeltetett rendszerek egyáltalán nem adnak megfelelő információt. A „How might we"-kérdés felvetésen keresztül alternatív megoldási javaslatokat kapunk a probléma - jelen esetben a multimodális utazástervező és ajánlatadó felület hiányának - kezelésére. Feltárhatjuk azokat a szük keresztmetszeteket, amelyek 
7. ábra: EGYJEGY forgatókönyvek - storyboard (képes forgatókönyv) SAP Scenes termék felhasználásával (részlet)

\section{Eset: Csalás térerőből}

Hát, ebböl nem derül ki hogy van-e jegye
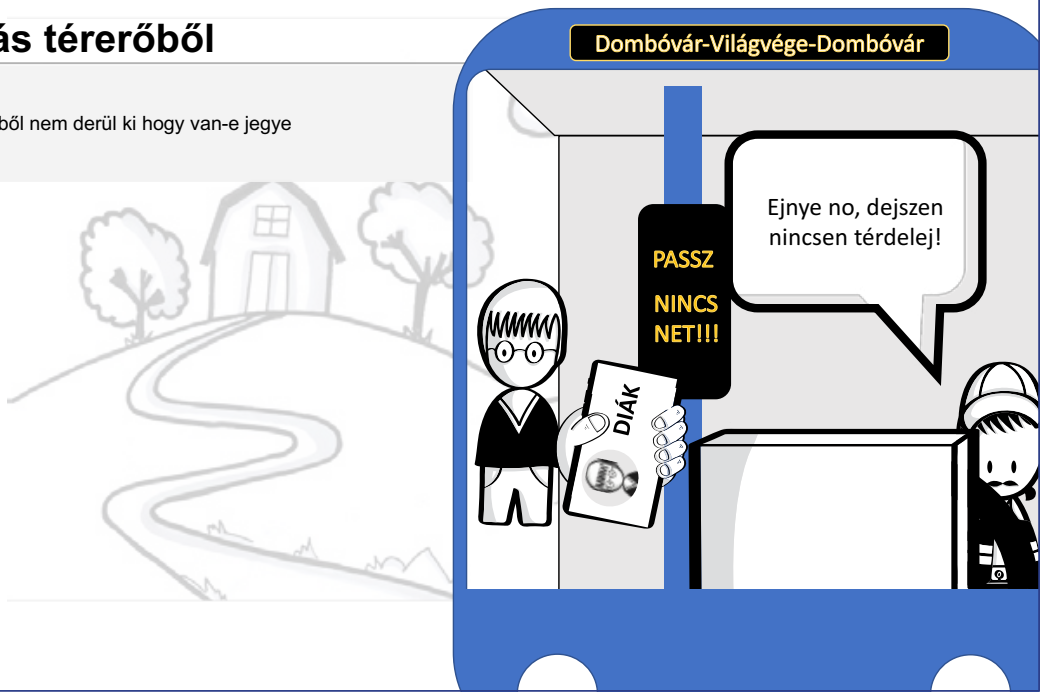

8. ábra: EGYJEGY forgatókönyvek - storyboard (képes forgatókönyv) SAP Scenes termék felhasználásával (részlet)

\section{Eset megoldás: központi ellenörzés}

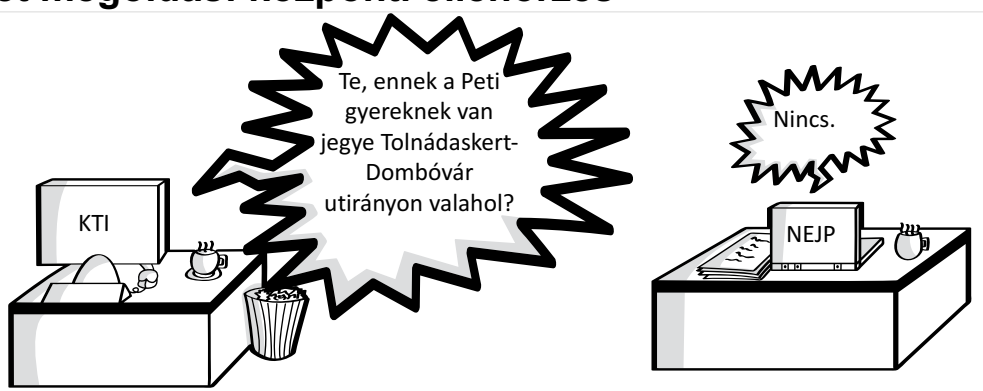

A kérdés továbbra is fennáll, de most egy picit máshogy nézzük

akadályozzák a megoldások megvalósítását, és egyben azonosíthatjuk a probléma kezelésével elérhető hatást, ami segít a célrendszer meghatározásában. A feltárt szűk keresztmetszet az esetben, ha a szolgáltatók nem érdekeltek abban, hogy saját rendszereikben megjelenítsék a többi, egyébként szintén közszolgáltatást végző közlekedési társaság menetrendjét, ajánlatait. Ennek feloldása pedig alternatív megoldás- ként az lehet, hogy a szolgáltatók „felett” kell létrehozni egy multimodális utazástervező és ajánlatadó rendszert. Ennek hatásaként meghatározható, hogy az utazástervezés egyszerüsödésével és átláthatóbbá tételével több utas veszi igénybe a közösségi közlekedést, ami amellett, hogy beépíthető a projekt célrendszerébe, megalapozza azt az alapelvet, miszerint egy országos, egységes rendszert kell létrehozni. 


\subsubsection{Jegyvásárlás}

A jegyvásárlás esetében azonosított egyik meghatározó probléma, hogy jelenleg az autóbuszos alágazatban a jegyvásárlások jelentős hányada közvetlenül az utazás megkezdése előtt, a busz fedélzetén a jármüvezetőnél történik. Ha erre a probléma felvetésre azt a kérdést tesszük fel, hogy „hogyan oldanánk meg azt, hogy az utasok ne a fedélzeten vegyenek jegyet?", számtalan alternatíva megfogalmazható válaszként. Az akadály az, hogy jelenleg szűkösen állnak rendelkezésre azok az értékesítési csatornák, ahol a jegyelővásárlási lehetőségek biztosítottak. Erre az egyik megoldás, hogy bővíteni kell az önkiszolgáló értékesítési csatornákhoz való hozzáférést. Ennek hatása, hogy az utas kiszámítható módon, önállóan megtervezi és megvásárolja az utazási jogosultságát.

\subsubsection{Utazás terv szerint és a tervtöl eltéröen}

„Vajon hamarosan továbbindulunk vagy inkább szálljak le?” - talán ez a leggyakoribb kérdés abban az esetben, amikor az utas az utazás közben egy havária helyzetbe kerül. A probléma az, hogy nincs információja a kialakult helyzetről, arról pedig végképp nem, hogy ebben a szituációban milyen alternatívái lehetnek az utazás folytatására, vagyis „Hogyan oldanánk meg, hogy valós időben érdemi információt kapjunk a döntéshez?”. A szűk keresztmetszet jelenleg, hogy nincs egyértelmüen egy olyan platform, ahol az esetlegesen megfogalmazott kérdéseire választ kaphatna, hiszen adott esetben még a humán személyzet (jegyvizsgáló, buszvezető) sem rendelkezik információval, rálátás hiányában a teljes közlekedési rendszerre. Egyrészről megoldásként fogalmazhatjuk meg, hogy létre kell hozni egy, a teljes közlekedési hálózatot operatív irányító központi rendszert, másrészről egy olyan platformot, ahol az utasok tájékozódhatnak a közlekedési rendszer valós idejü állapotával kapcsolatban, az őket érintő változásokról a lehető leghamarabb értesülnek, és ezért lehetőségük van ezen változásokra reagálni. Hatásként megfogalmazható, hogy a tervezett utazások még zavarhelyzet esetén is kiszámíthatóbbá válnak, az utasok kiszolgáltatottság-érzete csökken és az adott kritikus szituációkban a döntési képességük jelentősen nő és közelít ahhoz, amit az egyéni közlekedésben megszoktak.

\subsubsection{Utazás után}

1831556 percet, vagyis közel 3,5 évet késtek a személyszállító vonatok az elmúlt évben olvashattuk az Index 2018 tavaszán megjelent cikkében [21]. A cikk egy általános jelenségre, a vonatkésések gyakoriságára hívja fel a figyelmet, de nem szerepel benne az az adat, hogy a szolgáltatók mennyi, az utasokat - jogszabály vagy üzletszabályzat alapján megillető - késés utáni kártérítést fizettek ki. Ezzel el is jutottunk az egyik legfontosabb utazás utáni ciklusban azonosított problémához, ahhoz, hogy a vonatkozó szabályok bonyolultsága és az adminisztratív akadályok (igazolások, különböző nyomtatványok) miatt az utasok nagy többsége nem érvényesíti a késés utáni jogos kártérítést és más (reparatív) jogaikkal - viszszatérítés, csere, menetjegy érvénytartamának hosszabbítása stb. - is csak kevesen élnek. „Hogyan oldanánk meg, hogy az utasok jogaikat adminisztratív akadályok nélkül érvényesíthessék?” - kérdeztük. Szűk keresztmeteszet jelenleg a késés tényének megállapításához szükséges adatok összevetésének nehézsége (utaspanasz - igazolás - késési tényadatok). Az egyik lehetséges megoldás ennek kezelésére egy olyan rendszer kialakítása, ami a rendelkezésre álló adatok (értékesítési adat, érvényesítés/ellenőrzési adat, vonatkozó szabályok, menetrendi tényadatok) alapján automatikusan téríti meg az utas felé a jogos kártérítést. A szolgáltatás nem megfelelő teljesítése utáni automatikus kártérítés fizetési kötelezettség, hatással lehet a szolgáltatás színvonalának növeléséhez, utas szempontból pedig a szolgáltatás iránti bizalom nő.

A workshopok alkalmával az utas életciklus egyes elemei részletesen, mélységeiben kidolgozásra kerültek és a résztvevők aktív bevonásával a legszélesebb körben azonosítottuk a közösségi közlekedési rendszer jelenlegi müködési problémáit. A fenti pontok mindössze kiragadott példákkal szemléltetik az alkalmazott módszertant, a következő fejezetekben 


\section{Közösségi közlekedés - szolgáltatásfejlesztés}

bemutatandó alapelvek és kialakítandó rendszerrel szembeni elvárások megfogalmazása egy sok körös, iterált folyamat eredményeképpen alakultak ki.

\section{A KIALAKULT ALAPELVEK}

A HKIR arra hivatott, hogy egy egységes keretrendszert biztosítson a magyarországi közösségi közlekedés müködésére, lehetővé téve a jelenlegi szolgáltatók hatékonyabb munkáját, a transzparens együttmüködést és a piacnyitást. Az értékesítési és utastájékoztatási alapelvek a rendszer működőképessége, fenntarthatósága, fejleszthetősége mellett az utasok számára az élményszerűséget nyújtja, ezzel a közösségi közlekedés versenyképességének szolgálatába áll.

\section{1. Önálló utas}

A most felnőtt milleniumi generáció és az utánuk következő generációk elsődleges igénye az önállóság: elvárják, hogy önállóan legyenek képesek igénybe venni a rendszer szolgáltatásait, mások segítsége nélkül, függetlenül az utazási paraméterek bonyolultságától vagy épp a saját hiányosságaiktól.

Ezért a rendszer folyamatosan támogatja az önkiszolgálást, az önálló tájékozódást, teljesen akadálymentes, és a lehető legkevesebb mentális és fizikai terhelést okozza. A hibahelyzetekben tisztában van vele, hogy az emberek egyéni és önálló döntéseket szeretnének hozni a saját közlekedésükkel kapcsolatban, ezért erre a lehető leghamarabb, az utas fogalmainak, helyzetének, cselekvési lehetőségeinek megfelelő információkat ad.

\subsection{Teljes utazásmenedzsment}

Senki nem a buszmegállóban lakik és általában nem a vasútállomáson dolgozik, az utazás se áll meg itt, ahogy a versenyképesség is az egyéni közlekedésben felmerülő parkolással, autófenntartással együtt ítélhető meg. Így a helyi közlekedési megoldásokat, ideértve a busz-, közbringa, közautóközlekedést, valamint az egyéni közlekedést (parkolóhelyek, bicikliszállítás, biciklitárolás) is figyelembe kell venni.

\subsection{Egy nyelv}

A rendszer konzekvensen azonos fogalmakat, színeket, szimbólumokat használ a felhasználói számára, hogy ezzel is segítse az önállóságot. Minden környezetben, minden szolgáltatónál azonnal felismerhetőnek kell lennie a rendszer komponenseinek (validátorok, automaták, pénztárak).

Az utazóközönség akkor lehet önálló, ha a kulturális kontextusának megfelelő nyelvezetet kapja: így a külföldi és belföldi nevezéktan nem tükörfordítása egymásnak, ahogy a pénztárosnak sem kell folyamatosan körülmagyarázni az elemeket.

\subsection{Egy rendszer és egységes rendszerköve- telmények}

A teljes országos (helyközi) közösségi közlekedést egyetlen rendszer szolgálja ki, amely kapcsolódik a helyi közösségi közlekedési rendszerekhez is. Mindenki, aki Magyarországon igénybe akarja venni az államilag támogatott közösségi közlekedési megoldásokat, ezen a rendszeren keresztül tudja igénybe venni azt. Ez azt is jelenti, hogy az összes értékesítési csatornán ugyanaz a rendszer üzemel, legyen az jármüfedélzet, pénztár vagy mobiltelefon, vasút, busz vagy hajó.

Az egységességnek egyszer feltétele, mászszor következménye néhány fontos müszaki alapelv:

\subsubsection{Robosztus}

A rendszer tisztában van vele, hogy az emberek és a gépek is hibáznak, az állomány pedig folyamatosan romlik: az egyes hibák a lehető legkevésbé befolyásolják a müködését, tetszőleges helyzetből képes felállni 24 órán belül, elfogadja, hogy nincs internet elérhetőség mindenhol, a jegybemutatásra többféle módot biztosít, és mindig, minden csatornán vissza lehet referálni a kontakt centerre. A födiszpécseri központ feladata az üzemzavari anomáliák intermodális kezelése. 


\subsubsection{Reziliens (ellenálló)}

A rendszer tervezett élettartama meghaladja a jelenlegi müszaki kereteket, ezért képes kezelni tetszőleges jármüvet, tetszőleges utazási módot, tetszőleges piaci környezetben képes működni, tetszőleges azonosítási, fizetési módokkal. Függetlenül attól, a jövő utópiaként vagy disztópiaként valósul meg, a rendszer müködöképes marad és alkalmazkodik a gazdasági, jogi környezethez.

\subsubsection{Smart}

A rendszer minimalizálja az emberi beavatkozást, és bár arra a robosztusság elvén folyamatos lehetőséget ad, működését tekintve automatikus, az emberi erőforrások vezénylésében is operatívan részt vesz, terveket, javaslatokat ad.

\subsubsection{Adatvezérelt}

A rendszer folyamatosan gyüjti az adatokat a saját működéséről, ezeket az üzemeltetésben résztvevőknek, az utasoknak, és a tervezést, szabályozást végzőknek folyamatosan visszacsatornázza és kommunikálja. Az üzemeltetés statisztikai és tényadatok, valamint predikciók alapján végzi a munkáját, az utasok tisztában vannak a közlekedési rendszer valós idejü állapotával, az őket érintő változásokról a lehető leghamarabb értesülnek, és lehetőségük van ezen változásokra reagálni.

\subsubsection{Igényorientált}

A rendszer ott müködik, ahol utazási igény van: ezért kiemelten foglalkozik a havária esetén bekövetkező utazási igények rendezésével, folyamatosan elemzi az utazási szokásokat, lehetőséget teremt kihasználatlan kapacitások ideiglenes vagy teljes lekapcsolására, átcsoportosítására, a bejövő utasigényekhez pedig döntéstámogatást nyújt, átfogó elemzésekkel és külső adatok figyelembevételével.

\section{KONKLÚZIÓ}

A Service Design módszertan reményeink szerint biztonságos keretet ad a rendszer tervezésének, és biztosítja, hogy a rendszer alakí- tásában a legkevésbé aktív, a legvédtelenebb, ugyanakkor a legfontosabb szereplő jár jól: az utas. A HKIR a kétségtelen technikai fejlődésen kívül alkalmas legyen arra, hogy a potenciális és a tényleges utasok széles tömegei számára érthető, egyértelmü, kiszámítható eszközöket biztosítson az értékesítési és az utastájékoztatási csatornák használata során egyaránt. A kitűzött élménycélnak megfelelően a HKIR az utazás egészének megítélésén - áttételesen a közösségi közlekedés versenyképességén - megfelelő kialakítás esetén nem ront, éppen ellenkezőleg: az utazási lánc megvalósulása során bekövetkező kellemetlenségeket részben ellensúlyozni tudja.

\section{FELHASZNÁLT IRODALOM}

[1] Németh Á., Gyúri A.: Felhasználóbarát felületek tervezése, Masterfield Oktatóközpont, 2017

[2] Handel, S: Classification of Emotions, http://www.theemotionmachine.com/ classification-of-emotions/

[3] Dr. Tóth-Maros D.: Vasúti személyszállítási szerződéstan, Baross Gábor Oktatási Központ Budapest, 2017.

[4] Catalanotto, D: A Tiny History of Service Design (Blurb, 2018, online elérhető itt: https://service-design.co/book-a-tinyhistory-of-service-design-368ed603797c )

[5] http://iris.cs.aau.dk/tl_files/volumes/ volume07/no1/04_bjerknes_p73-98.pdf

[6] Card, S.K., Moran, T.P., Newell, A.: The Psychology of Human-Computer Interaction, Lawrence Erlbaum Associates, 1983

[7] Shostack, G. Lynn. "Designing Services that Deliver", Harvard Business Review, vol. 62, no. 1 January - February 1984, pp 133-139

[8] Norman, D.A., Draper, S.W.: User Centered System Design; New Perspectives on Human-Computer Interaction, Lawrence Erlbaum Associates, 1986 DOI: http://doi. org/ddn6

[9] Rowe, P: Design Thinking, MIT Press, 1987

[10] Alexander, C: A Pattern Language - Towns, Buildings, Constructions, MIT Press, 1977

[11] Brown, T.: Change by Design: How Design Thinking Transforms Organizations and Inspires Innovation, Harper Collins, 2009 


\section{Közösségi közlekedés - szolgáltatásfejlesztés}

[12] Bhavnani, R., Sosa, M.: IDEO: Service Design (A) INSEAD, 2006

[13] https://www.adaptivepath.org/ideas/ the-anatomy-of-an-experience-map/ (2011.11.31)

[14] Németh Á.: UX A MÁV-STARTnál, HWSW Mobile! konferencia, 2015

[15] Németh Á.: A JÉ projekt megújuló belső rendszerek felhasználói felületei - terepkutatási és tesztelési eredmények (belső dokumentáció, 2017)

[16] Németh Á., Balog Z. T.: A MÁV-START szolgáltatásainak ergonómiai problémái az utas életciklusának függvényében (UXStratégia, 2018)

[17] Földesi F.: Az EGYJEGY rendszer fejlesztési irányainak meghatározása a potenciális fel- használók igényei alapján, diplomamunka, Budapesti Müszaki Egyetem, 2018

[18] ISO: ISO 9241-210:2010 Ergonomics of human-system interaction - Part 210: Human-centred design for interactive systems (ISO, 2010)

[19] Ridson, C., Quattlebaum, P.: Orchestrating Experiences: Collaborative Design for Complexity, Rosenfeld Media, 2018

[20] Lego: Introduction to Lego Serious Play, Open source version The LEGO Group, 2010 (online: https://www.lego.com/en-us/ seriousplay/background, 2019. 02. 11.)

[21] https://index.hu/gazdasag/2018/04/12/ mav_keses_2017/ (2018.04.12)

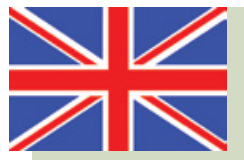

\section{Travel experience in ticketing and passenger information: Transport Service Design}

Why do passengers feel lost while travelling, and what do they understand from the events around them? Is the "complexity" of transport a barrier to competitiveness? The HKIR (Interurban Community Transport Information System) is the most complex public transport information technology project in Hungary to date, which will determine passenger experience for decades after its introduction, and frame the cooperation between the players of interurban transport. The following paper presents the basic principles by which the creators build the system and how they have arrived at them.

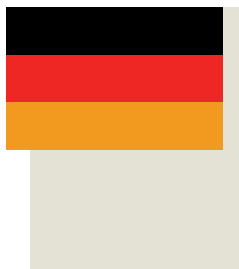

Warum fühlt sich ein Passagier während der Reise verloren, was versteht er von den Ereignissen um ihn herum? Ist die "Komplexität" des Verkehrs ein Hindernis für die Wettbewerbsfähigkeit? Das HKIR (Informationssystem für den Öffentlichen Überlandverkehr) ist das bislang komplexeste Projekt in Ungarn auf dem Gebiet der Informationstechnologie für den öffentlichen Verkehr. Nach seiner Einführung wird es über Jahrzehnte das Fahrgast-Erlebnis bestimmen und die Rahmen der Zusammenarbeit zwischen den Teilnehmern im Fernverkehr regeln. Im Folgenden es wird geschildert, auf Grund welcher Prinzipien die Autoren das System erstellt haben, und auf welche Weise sie dazu gekommen sind. 